\title{
THE LEGAL THEORIES OF JAMES WILSON
}

"Without detracting, therefore, from the real merits which abound in the imperial law, I hope I may have leave to assert, that if an .Englishman 'must be ignorant of either the one or the other, he had better be a stranger to the Roman than to English institutions." Such was the spirit in which Blackstone approached his task, not with the enthusiasm of a narrow nationalism, but with the mild suggestion that that which is the fruit of English experience is of more immediate significance in dealing with English problems than the experience of Rome or Byzantium. This is the spirit in which this essay is made to call attention to the legal theories of an American jurist who seems to epitomize the spirit of American legal institutions in the time when they were first emerging as distinct from the institutions of England.

James Wilson emigrated from his birthplace in Scotland to America in the days when John Dickinson was one of the leaders of the Philadelphia Bar. Wilson studied law in Dickinson's office prior to the outbreak of the Revolution; he was one of those pre-revolutionary pamphleteers who tried to make clear the nature of the British Empire as a commonwealth of nations, rather than as a centralized and consolidated state. When those efforts were of no avail he threw in his fortune with the patriot party. The outbreak of the war found him a member of the second Continental Congress. He has the remarkable record of being one of those six men who signed both the Declaration of Independence and the Constitution of the United States, and he has the unique distinction of being the only member of Pennsylvania's rather large delegation to the Federal Convention, who was also elected a member of the Pennsylvania State Convention which ratified the Federal Constitution. The part he played in those meetings is evidenced by the historical and legal comments which have been made upon him 
"that he was the most learned lawyer of his time," "one of the deepest thinkers and most exact reasoners among the members of the convention," "the real founder of what is distinctive in our American jurisprudence," "recognized as the most learned member of the constitutional convention," "ablest and most learned of the associates" on the Supreme Court of which he was a member."

James Wilson's notable services in the period after the revolution have secured his place in the political history of the United States, ${ }^{2}$ but it seems extremely questionable whether what we may call the science of jurisprudence has accorded to him the place to which he is probably entitled. That question becomes even stronger when one hears some of the professors of international law proclaiming from their chairs either that there is no such thing as international law, or else hears those gentlemen define law in such terms as to give international law no place. For such writers and lecturers one feels a little disposed to paraphrase Blackstone, and, as he advised Englishmen not to sacrifice Alfred and Edward to Theodosius and Justinian, so to suggest that perhaps they might find it of practical value not to sacrifice James Wilson to John Austin and his school. The difference between the sense and definition of law upon which the era of the American Revolution depended for its politico-juridical thought and that which has produced a great deal of modern ante- and post-bellum chaotic thinking, can, it would seem, be nowhere better illustrated than by an examination of the legal theories of Wilson.

One can do little better than to follow his own advice, to consider that "law should be studied and taught as a historical science," 3 and to regard his legal theories as part of the history of that science. In the opening lecture before the students of the Law School of the"University of Pennsyl-

1 The comments of McMaster, Bryce, S. E. Baldwin, J. M. Harlan and Cooley; for appreciation see L. H. Alexander in The North American Review, CLXXXIII: 97 I (1906).

2 A. C. McLaughlin: Political Science Quarterly: XII, I.

'James Wilson's Works (Bird Wilson ed.) (Phila.: 1804). Citations throughout are to this, the first edition of Wilson's works. I, 5 . 
vania, where Wilson was the first professor of law in 1790 , the lecturer remarked "Were I called upon for my reasons why I deem so highly of the American character, I would assign them in a very few words-that character has been 'eminently distinguished by the love of liberty and the love of law." Quite different was Blackstone's opening in his first lectures as Vinerian professor at Oxford wherein he specifies the laws and constitution of England as being a "species - of knowledge, in which the gentlemen of England have been more remarkably deficient than those of all Europe besides. 5 Was Blackstone merely the more modest and Wilson merely the more boastful of the two, or were they talking about two different things when they used the terin "law?" But let that story tell itself. If it be tiue that the "men of the revolution saw only two alternatives: freedom or slavery"، it is equally true that the men of the Revolution understood with a clearness which history cannot too frequently emphasize, that freedom without the limitations of law was worse than slavery. "Without liberty, law loses its nature and its name and becomes oppression. Without law, liberty also loses its nature and its name and becomes licentiousness." This, after all, was a permanently valuable political philosophy of the American Revolution. Carefully documented historical explanations of the American Revolution in terms of taxation, the Acts of Navigation or the com'petition for commerce cannot but eclipse the element of sound political thinking in which the founders of the republic delighted. Yet if we seek a picture of the early republic, we find that political thinking in the abstract occupied a much larger place than it does in the political science of the twentieth century. It is a fact which cannot be neglected, however much it may be minimized.

The men who were the product of the intellectual ancestry of which James Wilson was but one of many, understood the interrelationship of law and liberty and they conceived

'Wilson's Works, I, 5 .

$5 \mathrm{Bl}$. Com. Intro. 4.

${ }^{6}$ C. E. Merriam: American Political Theories, 53. 
of liberty as freedom according to law. They threw off the yoke of England, not as law-breakers but as preservers of the law. It is well known that independence was far from the minds of the bulk of the citizens of the American colonies when the first Continental Congress met. ${ }^{7}$ What they wanted was liberty under the limitations prescribed by the British Constitution. They were being persecuted by the real law breakers, for such was the parliament which had violated that Constitution. "Have not British subjects, then, a right to resist such force, force acting without authority, force employed contrary to law, force employed to destroy the very existence of law and of liberty? They have, sir, and this right is secured to them both by the letter and the spirit of the British Constitution, by which the measures and the conditions of their obedience are appointed. The British liberties, sir, and the means and right of defending them, are not the grants of princes; and of what our princes never granted they surely can never deprive us."8 It seems to be the peculiarity of an Anglo-American Revolution that it is conducted, not so much for completely overturning the old order and making a new lot of laws, but rather for the sake of getting the benefit of those rights which the old laws assured them anyway, but which the particular government is withholding. That is a fact which should never be obscured in trying to get at the conception of law in the period of the American Revolution. Law was not merely some convenient rule, which might be adopted one day and rejected the next at the whim of some assemblée nationale or soviet. Law was something a good deal more fundamental than that.

To James Wilson there were two totally distinct bodies of law: natural laws and human laws. The political think-

7 "As our proceedings during the existence and operation of the Stamp Act prove fully and incontestably the painful sensations that tortured our breasts from the prospect of disunion with Britain; the peals of joy which burst forth universally upon the repeal of that odious statute loudly proclaim the heartfelt delight produced in us by a reconciliation with her." Wilson's speech in the Convention of the Province of Pennsylvania, January, I775. III: 251 .

Ibid: III, 262-3. 
ers of the eighteenth century frequently confused them elaborately. Wilson separated them, clearly, distinctly and serviceably. The natural law was the immutable, universal moral law, the will of God. It would indeed be valuable to know more about it. But it is hardly a subject to be treated in this effort and in this day when men are less confident than they were formerly of their ability easily to penetrate into the counsels of the Almighty. Hence we turn to the more modest task of trying to explain what James, Wilson called human laws, and in that field there is much to be done. This was what Wilson saw with such vividness when he set himself to attack the views of many of the publicists of his day on the nature of law. Those views presented just the same confusion of ideas and lack of clear thought that is manifested today in connection with that department of law which is known as international law. The stumbling block lay in the question of the definition of law, for upon that depended the question of obligation. Is it law, if it is not observed? Such a question springs from a conception of law quite familiar in the writings of publicists from Puffendorf to Blackstone and from Blackstone to Austin. The view that law is a command given by a superior to an inferior which the inferior must obey upon the pain of some sanction, is an easy and a simple thing to understand. But, as has been observed, it leaves no room for such branches of law as international law. After all, the contributions which America has made to international law, both of letter and of spirit, are of such a character which cannot but turn our inquiries toward some more representative American conception of law than that given by Blackstone or Austin. Such a conception formed a part of that political philosophy of the American Revolution in which so many of our national ideals took form, and there are few jurists in whose writings it comes out so clearly as in those of Justice Wilson.

"Law is a rule of action" had said Blackstone, "and it is that rule of action which is prescribed by some superior and which the inferior is bound to obey." At this point

9 Bl. Com. Intro., 38. 
the new professor of law in the new American University took issue with the Vinerian professor. "A superior! Can there be no law without a superior? Is it essential to law that inferiority should be involved in the obligation to obey it?"10 Here Blackstone has exhibited just that confusion of natural and human laws which Wilson was at pains to differentiate. Certainly, there were natural laws, which presumed the existence of a superior, God, but to confuse these with human laws was to presume that God had some temporal deputy on earth to whom he had confided the power of enunciating his law. This was in essence that divine right of kings which the revolutionary thought of both England and America had overthrown. Such a conception of law as Blackstone prescribed was the essential element of " a prerogative impiously attempted to be established-of princes arbitrary to rule; and of a corresponding obligation-a servitude tyrannically attempted to be imposed-on the people implicitly to obey." 11 It was the introduction of superiority as a necessary part of the definition of law to which Wilson objected. The idea itself is as old as Rome and as tyrannous as Caesar. "Indeed on the principle of superiority, Caligula's reasoning was concise and conclusive, 'If I am only a man, my subjects are something less; if they are men, then I am something more." 12 Such would be the logical and necessary conclusion of attributing to a superior the authorship of human laws. Could such a conclusion ever be brought into line with the American political principles as set forth in the American constitutional documents? It is difficult to see how they could. For these were human laws, and once the element of superiority and inferiority was introduced the element of the equality of man was lost.

Such a proposition arouses at once the question, what about the state? Did not, or would not he admit that the state was superior to the individual? The question is a

${ }^{10}$ Wilson's Works, I, 65 .

11 Wilson's Works, I, 66.

12 Wilson's Works, I, 92. 
difficult one to answer, for Wilson's utterances do, not at first glance seem to be altogether consistent in this matter. But a little reflective reading seems to make the matter not such a difficult one after all. In the first place the eighteenth century thinker never lost sight of the fact that political machinery existed for men, and not men for political machiery. Hence, when he personified the state, it was as a figure of speech, rather than as an act of awesome deification. Its dependence on the people which composed it was an essential element of the state. "In free states" says Wilson, "the people form an artificial person or body politic, the highest and noblest that can be known." In that definition the eighteenth century would have emphasized the words "people" and "artificial" in a way in which one might not emphasize them today unless his attention was especially directed to it. The "moral person" which was thus constituted was described "as a complete body of free natural persons, united together for their common benefit; as having an understanding and a will; as deliberating, resolving and acting; as possessed of interests which it ought to manage; as enjoying rights which it ought to maintain, as lying under obligations which it ought to perform. To this moral person, we assign by way of eminence, the dignified appellation of 'state." "13 In discussing the rights and duties of a state he observed "that it is its right and generally its duty, to form a constitution, and to institute civil government and to establish laws." From this the hasty reader might conclude that after all the state was the "superior" which made the laws, and hence that after all, Blackstone was quite right. But such a conclusion would miss the whole spirit of the Revolutionary philosophy. There is nothing quite like a debate to make a man show his whole hand, and hence we may look for Wilson's own interpretation of his idea of the state in that great debate with which the United States began.

In the Federal convention of 1787 the idea of a "state" was a thing very much more clear-cut than ordinarily comes

${ }^{13}$ Wilson's Works, II, I20-I. 
to mind when that word is used today in connection with one of the component members of the federal union. There were small-states men, and large-states men, and there were states-rights men. But they were a great deal more "stateconscious" than one would imagine who lives in the twentieth century when the word "state," in connection with the United States, has become a relatively less important and less thought about entity. Yet, it was probably with just some such idea of the nature of the state as Wilson defines it above, that the states-rights men and the smallstates men urged the claims of their states. There was a "state-sensitiveness" in that day which has been distinctly on the wane since the War between the States. Consequently, if we would get ourselves in the proper mental attitude to understand the thought of a past era, we must understand what they meant by words which in the day have assumed a different connotation. When on that memorable thirtieth of June, the federal convention seemed deadlocked because the small-states men insisted upon equal rather than proportional representation, the rights of the "states" were urged in a language which betokens the existence in the minds of the states-rights men of an idea of "state" which is a good deal more consistent with the technical sense in which that word is used today, i. e., as an individual member of the family of nations. Delegates talked of their right to join some foreign power, in case their wishes were not granted. ${ }^{14}$ Then it was that James Wilson uttered those words which more clearly delineate his conception of the relationship between the people, the law of the constitution and the state than we can glean from some didactic utterance from a lecture platform. "If the minority withhold their consent to the new plan, if they will have their own way and go out of the union, then let them go. Shall threefourths be ruled by one-fourth? Shall three-fourths give up their right for the support of an artificial being called Stateinterest? For whom do we make a constitution? Is it for

"Farrand: Records of the Federal Convention, I, 50I. 
men, or is it for imaginary beings called states, a mere metaphysical distinction?"15 What Wilson was trying to help build was a national state, and not a confederacy; hence when those spoke who had the confederacy idea in mind, his chief argument lay in showing his colleagues that the state existed for the people and not the people for the state. Consequently if the people wanted one national unit, they were entitled to have it and not to blocked by acutely-stateconscious delegates who seemed to regard the state as a thing in itself, and consequently wanted a confederacy of states. ${ }^{36}$

Consequently, to have asked James Wilson whether or not he regarded the state as superior to the individual, he would probably have said that such a question betrayed an unfamiliarity with the true nature of law. A State was merely an aggregate of people, which expressed its will in the law of the constitution, which in turn formed a government. To endow a state with a metaphysical or a spiritual nature, to grant it an existence above or apart from the people was totally to misunderstand the thought of the Revolutionary period in America. Nowhere does this come out more clearly than in Wilson's discussion of sovereignty: the sovereignty of the state was not a term in which he thought; the sovereignty of the people was all he understood. ${ }^{17}$

Now, if the element of superiority were permitted. to remain in the definition of human law, mankind would be compelled to answer the question as to whether this was a superiority of force or of excellence, by which the superior claimed his right to impose his will upon the inferior. The former is exactly what Anglo-American revolutions were fought to avoid, and it is easily disposed of. "For us, as men, as citizens, as states," it is sufficient to say that power is nothing more than the right of the strongest, and may be

${ }^{15}$ Farrand: Records of the Federal Convention, I; 494.

${ }^{16}$ See also Wilson's Works: I, 360 , where he uses "State" and "Society" interchangeably.

${ }^{17}$ Wilson's Works, I, 25. 
opposed by the same right, the same means and the same principles which are employed to establish it. "Bare force, far from producing any obligation to obey, produces an obligation to resist." 18 On the other hand if the superiority be based upon excellence, if the superior claim any superiority by virtue of his being more wise, who will take upon himself to make such a judgment. To speak of superiors, involves the implication that there are inferiors; is government consciously to take cognizance of the inequalities of men? If so, what is the standard? "Is this a foundation sufficient for supporting the solid and durable superstructure of law?"19

Wilson's knowledge of comparative governments was necessarily more limited than would be the case today, yet it is remarkable how carefully he selects the illustrations with which his points are elucidated. The classic references abound, of course; he would not have been a true representative of the eighteenth century if they had not. But his reading in the political scientists of all nations was extensive; not merely among the English and French writers, but among the continental writers of his day as well. Yet he never forgets the essential distinction which makes his work of such practical value, namely the separation of the idea of the law which God makes and the idea of the law which man makes; for, although in the case of the former he would not deny the existence of a superior, yet in the latter he would do so, and manifests therein the germ of what is distinctively American in political science-government by the consent of the governed. "Let it be remembered all along, that I am examining the doctrine of superiority as applied to human laws, the proper and immediate object of investigation in these lectures. Of the law that is divine, we shall have occasion at another time to speak, with the reverence and gratitude that becomes us." 20 In consideration of this clear distinction since the alleged superior cannot rest his title on any inherent qualities as goodness or

18 Wilson's Works, I, 71.

${ }^{19}$ Wilson's Works, I, 74 .

20 Wilson's Works, I, 7 I. 
force, from what source can such superiority be derived? Divine source is ruled out by reason of the fact that it involves not human, but divine laws; and, if the two be confused, it being even more ruled out because it involves the divine right of kings, what source remains? "How is this superior constituted by human authority?"

Is the superior constituted by law? If he is, then the power which constituted that law is his superior, and we are confronted by the same question as before. ${ }^{22}$ So the will of a superior is discarded as an improper principle of obligation in human laws. It will stand the test of neither reason nor experience; it contains the germ of tyranny, and it provokes the alleged inferiors to resistance and revolt. The idea of law as a policeman's club is just the idea which Wilson would have his students avoid. However it might represent the law and the idea of law in foreign lands, it was not the Anglo-American idea as he understood it. Not that he was an advocate of pure moral suasion; far from it. He simply believed that that force which is the sanction of law was not the exclusive property of the alleged superior to do with it as he chose. The superior which existed for convenience's sake in administration, exercised whatever force he did only at the bidding of the alleged inferior, by whose consent he exercised also his temporary superiority.

Thus it is, that when asked what in his view was the essential element of law; which he would substitute for the idea of a superior with a sanction, he states unequivocally "In its place I introduce the consent of those whose obedience the law requires. This I conceive to be the true origin of the obligation of human laws." ${ }_{23}$ Customs were the first laws known to men; certain conventional habits of actions which mankind observed simply by reason of the necessary requirements of peaceful human intercourse. Customary law was rudimentary law, and when the conventional types of action crystallized into rules enforceable in the courts of

21 Wilson's Works, I, 83.

22 Wilson's Works, I, 85 .

${ }^{23}$ Wilson's Works, I, 99. 
law, the evolution of law might be said to have reached its latest stage. Customary law was not the dictate of a superior to an inferior. It was introduced by voluntary adoption, and became general by the simple process of instances of that voluntary adoption being multiplied. ${ }^{23}$ It became lasting by satisfactory experience, which ratified and confirmed what voluntaty experience had adopted and introduced. "In the introduction, in the extension, in the continuance of customary law, we find the operations of consent universally predominant." In the regulations of justice and of government, customs have been more effectual than the best of written laws. This view was in his estimation the only view that could be held by an eighteenth century lawyer. "Let us mention in one word, everything that can enforce my sentiments: the common law of England is customary law." 24 One need go no further to understand what Wilson conceived to be the essential nature, origin, and source of the obligation of law. Here was not necessarily any elaborate fiction of social contract or any discussion of the rights which mankind retained over and above what the limitations of the law took away from him. The simple distinction here made between common and statute law was no ultimate distinction in origin or obligation. The law which was produced by the enactment of legislative assemblies derived its obligatory force only from that same consent, given less formally, but none the less effectively in the formation of the customary law. "Where is the difference whether the people declare their will by their suffrage or by their conduct." 25 For "customs for a long time were the only laws known among men" and "custom is, of itself, intrinsic evidence of consent." ${ }_{26}$ In the AngloAmerican legal system Wilson could not regard statutory enactment as the only, or even the principal, species of law. That English Common Law, "founded on long and general custom," which in turn can be founded on nothing but free

24 Wilson's Works, I, 100.

${ }^{25}$ Wilson's Works, I, 64.

${ }^{26}$ Wilson's Works, I, 99, 100. 
and general consent, is the principal connotation which the word "law" had for him. ${ }^{27}$ To him the eighteenth century nomenclature was not his master, but his servant. Certainly he would admit of "compact," "contract," covenant," "bargain" and whatnot; "let them be called covenants, or bargains, or stipulations and anything similar to any of those, still I am satisfied, for still everything mentioned, and everything similar to everything mentioned, imports, consent. Here history and law combine their evidence in support of consent." ${ }_{28}$ This theory of the nature of law, Wilson regarded as quite different from those of Blackstone, whom he thought followed rather after Hobbes and Puffendorf. His own thought he traces back rather through Vattel and Locke. This, after all was typical of the political philosophy of the revolutionary period in America. ${ }^{29}$

If o le would understand James Wilson's place in the history of jurisprudence, it is not so much the comparison with Blackstone which elucidates his theories as it is the comparison with another English legal writer, of whom he probably never heard, as John Austin was born in the year in which Wilson began to lecture. James Wilson's legal theories were the product of many years study of the writers of many nations; but that studying was done in the intellectual atmosphere of the American Revolution in Philadelphia, where Wilson lived for many years. John Austin studied at the Inns, yet one cannot but feel that his jurisprudence was colored by those years spent studying in Germany in the intellectual atmosphere of the reaction after the Napoleonic Wars. At any rate, his doctrines furnish the antithesis which bring out the Wilson doctrine by contrast. To Austin, as to Blackstone, a law was a command "which proceeds from superiors and obliges inferiors." Yet he is more explicit and emphatic than Sir William. "The term superiority signifies might; the power of affecting others with evil or pain, of forcing them through fear of that

27 Wilson's Works, I, 206.

28 Wilson's Works, I, IOI.

20 Wilson's Works, I, 69, 82, 84. 
evil to fashion their conduct to one's wishes." "In short, whoever can oblige another to comply with his wishes, is the superior of that other, so far as his ability reaches; the party who is obnoxious to the impending evil being, to that same extent, the inferior." 30 Such was Austin's theory of positive law. Of course international law has no place by definition, for international law is customary law, par excellence. It is the idea of law from above, the obligation to obey which comes from the fear of a superior force, rather than the idea of a set of rules which men have agreed to observe and which derive their obligations from the consent of those men. As to which is the higher sense of law, is a question of demonstration. ${ }^{31}$

But if Wilson's legal theories give us the proper legally philosophical formula by which international law can be elevated to a more respectful place in the science of jurisprudence, that was quite an incidental consideration on his part. When he comes to that subject itself there is another contribution of another sort. The course of lectures, which includes everything from legal philosophy to torts and crimes, brings the I 8 th century law students, in the fourth session, to the "Law of Nations." Once more there is the clear cut distinction between those laws of nations which take their origin in the law of nature, in divine law, and those laws of nations which find their origin in consent. Of the former, any thorough study of Wilson must take account, but since we have assigned ourselves the less pretentious

so John Austin: Lectures on Jurisprudence, 3rd ed. (1869) I: the first lecture contains some interesting definitions, esp. 88-89. One of the clearest criticisms of Austin in more recent thought can be found in Paul Vinogradoff's book, "Common Sense in Law"-Chapter II.

${ }^{31}$ We are, perhaps, now, as never before, in a position to take historical cognizance of the effect of this distinction. The German has been accustomed to regard the American as a rather lawless person, a conclusion only heightened by the American's disregard for sign bearing the magic word "Verboten." The American has learned to regard the German as an unfair player, one who disregards the rules of the game, who hits below the belt. The one obeys commands; the other observes rules. The one derives his sense of obligation through a sense of fear; the other through a sense of fair-play. The one is the product of discipline, the other of sportsmanship. Possibly, one may even go so far as to say that the one is concerned with the letter spirit, and the other with the law. At any rate it is easy to see which is the product of the Austinian and which of the Wilsonian point of view. 
task of setting forth his views on human laws, we must hurry on to that investigation. Wilson's contributions to what he would call "the voluntary law of nations," or what we know as "international law" as opposed to "international morality," are scant indeed. He criticizes Grotius freely for applying so rigorously that rule of consent which he himself emphasized when dealing with law in the abstract. $\mathrm{He}$ is frankly more interested in international morality and expresses opinions which take the form of pious expressions of hope, rather than statements of practice. ${ }^{32}$ Should any of his students have dropped out at the close of this lecture, they would indeed have gotten little from this professor's exposition of the subject of international law. It is true that Wilson did but touch the deeper questions of this field, for to say "he who has made a promise to another has given that other a perfect right to demand the performance of the promise," is a statement which is hardly Machiavellian. On the obligations of treaties he is as explicit as any writer before or since: "Nations and the representatives of nations ought therefore to preserve inviolably their treaties and engagements: by not preserving them, they subject themselves to all the consequences of violating the perfect right of those to whom they were made. $* *$ In public as in private life, among sovereigns as among individuals, honesty is the best policy, as well as the soundest morality. Among merchants, credit is wealth; among states and princes, good faith is both respectability and power." 33 But the trouble with such pronouncements, then as now, was that such principles were rarely denied in theory, while flagrantly violated in practice, a fact which makes Wilson's conception of the nature of law the more important.

But fortunately he does not stop here. The ninth lecture of the series bears the interesting title "Of Man as a Member of the Great Commonwealth of Nations." Herein he conceives the nations of the world as dwelling togetherin that natural society, that "state of nature," which the com-

32 Wilson's Works, I, $149 \mathrm{ff}$.

${ }_{33}$ Wilson's Works, I, I76. 
pact theorist assured him had existed prior to government. Yet even in this natural society, states existed under law. For a state to make a figure in the great society of nations, it is sufficient that it be independent, i. e., "that it govern itself by its own authority." 35 But to secure justice in "the great society, equality is the basis and the rule. To this equality, the inferiority of subjection and the superiority of command are alike, repugnant. This equality of nations is the great and general foundation of national rights. In this matter no regard is had for names;" all were alike before the law of nations, whether empires, kingdoms, commonwealths or free towns. ${ }^{36}$ The abstract admission of this legal principle is of little value unless some machinery be provided for its administration, and consequently one inquires, how this right is to be secured in a world where war still exists, where "among nations, as well as among individuals differences and causes of differences will sometimes unavoidably arise." Since above independent nations no coercive authority exists to which recourse may be had for a decision of the controversies, there are several successive steps which should be taken. Controversies often happen in which neither party is intentionally wrong, where mere misapprehensions and mistakes are the cause of the friction. In such cases nothing more is necessary for amicable accommodation than candid conference and mutual explanation. Such is the simple method of bilateral diplomatic negotiation.

But "if the parties themselves, notwithstanding their peaceful and proper inclinations, cannot finally agree upon terms, according to which the differences may be adjusted, those terms in many instances be arranged and settled by the kind and benevolent mediation of a common friend," who should remember that his office is to conciliate and not

34 Wilson's Works, I, 360.

${ }^{35}$ Wilson's Works, I, 362 . Cf. John Marshall's "No principle of general law is more universally acknowledged than the perfect equality of nations. Russia and Geneva have equal rights." The Antelope, ro Wheaton 66, 122 (1825).

36 Wilson's Works, I, 364 . 
to judge. ${ }^{37}$ But if neither friendly negoation nor the benevolent mediation of a third power will avail, there is yet another method "by which mutual irritation and much more dreadful extremities may be prevented between those who have no common judge on earth to whom they can appeal. This method is to refer the matter in dispute to an award of arbitrators." ${ }_{38}$ If arbitration fail the next alternative is the summoning of an international congress "in which the differences of contending parties might be determined by those altogether disinterested in them; and in which, likewise some effectural means might be devised and carried into execution for compelling nations at war to conclude peace upon fair and equitable conditions." But as Wilson wrote this twenty-five years before even the very deficient Congress of Vienna, he had little historical data with which to elaborate this point. The congresses of the eighteenth century called for such purposes "were nothing more than pompous farces, acted with great parade, by those who wished to appear solicitous for accommodation, but who in fact were little solicitous to promote it." ${ }_{39}$ Beyond these methods of international conciliation he knew of nothing which legal practice would suggest other than reprisals which would be in most cases merely the stepping stone to war. So much for the law of nations as he knew it. It will be observed that all these methods depend for solution on the existence of rules of law to which the negotiators and arbitrators may appeal, yet they are not rules or commands given by a superior to an inferior, because in international affairs there is no superior.

But Wilson was too good a political scientist to stop there. "All the modes of adjustment which have hitherto been mentioned presuppose the reconciliation of irritated minds" is the way in which he introduced his own theory of solving the problems of war. "But must the peaceful adjustment of controversies between states, and adjust-

37 Wilson's Works, I, 365.

${ }^{33}$ Wilson's Works, I, 365.

s9 Wilson's Works, I, 367 . 
ment so salutary and so necessary to the human race, depend on events so precarious or so very improbable? Must the alternatives in disputes and differences between dignified assemblages of men, known by the name of nations, be the same which are the prerogative of savages in the rudest and most deformed state of society-voluntary accommodation or open war, or violent reprisals, inferior in odium only to war? Individuals unite in civil society and institute judges with authority to decide, and with authority also to carry their decisions into full and adequate execution that justicemay be done and war may be prevented. Are states too wise or too proud to receive a lesson from individuals? Is the idea of a common judge between nations less admissible than that of a common judge between men? If admissible in idea, would it not be desirable to try whether the idea may not be reduced to practice? To return to the original question-has or has not our national constitution given us an opportunity of making this great and interesting trial?"40

In a word, Wilson was struck with the idea which has occurred to many men since his day, that the United States Supreme Court was in effect an international tribunal for the settlement of dispute between states. As a matter of fact, that is just the function that the Supreme Court has frequently exercised, administering international law, and being guided in its decisions by the principles of that law. ${ }^{4 r}$ It was obvious to Wilson in the second year of the Supreme Court's existence that being authorized to take jurisdiction in cases between states claiming to be sovereign, it would form an interesting object of study for comparative juris-prudence as an example of an international court. As a product of the English Common Law system, Wilson could not but be impressed with the latent possibilities of such a court, proceeding along lines analogous to those of the English Common Law Courts, administering a customary international law, which was akin to the customary common law,

10 Wilson's Works, I, 377.

${ }^{41}$ See R. I. v. Mass. 4 How. 49 I and Va. v. Tenn. I48 U. S. 503, 522-4r and authorities cited thereunder. 
and in certain sense even a part of it. Hitherto international law "has been applied and administered by the force or at the pleasure of the parties to the controversy: in the United States it can now be applied and administered by impartial, independent and efficient though peaceful authority," in such cases as come within its jurisdiction. To Wilson's imagination this idea opened up a magnificent prospect of the government of law, and of international peace based upon the existence of a court for the judicial settlement of international disputes. His dream of world peace was not :so much in terms of a super-state as it was in terms of a supercourt. 12

It is probably superfluous now to point out that the -effectiveness of such a court would depend entirely upon the sense of law possessed by those who submit their cases to it. If the litigants in such a controversy felt that the law thus administered was merely the dictate of a superior, and if the actions of the court were such as to justify that opinion, such a court would have little value. If on the other hand the litigants possessed the spirit of fair play and a willingness to abide by rules because of their personal interest in the making of those rules, and if the courts were actuated by a like motive, Wilson's dream was not a vain thing. But the whole question depends upon the acceptance of his original and fundamental legal theories.

Philadelphia, April I, тو20

Randolph C. Adams

42 Wilson's Works, I, 380. 